Editorial Office : Faculty of Law, Andalas University

Kampus Pancasila, Jalan Pancasila Nomor 10 Padang, West Sumatera

Phone/Fax : 0751-27404 / 0751-34605

E-mail : nagarilawreview@gmail.com | Website : nalrev.fhuk.unand.ac.id

\title{
Keabsahan Perjanjian dengan Klausul Baku
}

\author{
"Tessa Kurniawan"
}

\begin{tabular}{ll}
\multicolumn{2}{l}{ ARTICLE HiSTORY } \\
\hline Received & $: 28$ October $2017 ;$ \\
Reviewed & $: 28$ April 2018; \\
Accepted & $: 30$ April 2018; \\
Published & $: 30$ April 2018.
\end{tabular}

KEYWORDS

Agreement; standardized contract; validity.

CORRESPONDENSE

${ }^{1}$ Fakultas Hukum Universitas Ekasakti

\section{Pendahuluan}

Penggunaan kontrak baku dewasa ini menunjukkan satu sisi dominasi ekonomi modern oleh badan usaha atau perusahaan. Perusahaan-perusahaan menciptakan bentuk kontrak sebagai bagian untuk menstabilkan hubungan pasar eksternal mereka ${ }^{1}$. Dengan alasan keseragaman dan efisiensi perusahaan telah merumuskan seluruh atau sebagian besar klausul perjanjian secara sepihak. Pihak konsumen tidak memiliki kesempatan untuk menegosiasikan isi perjanjian. Konsumen hanya memiliki pilihan take it or leave it.

1 Ridwan Khairandy. (2007). “Keabsahan Perjanjian Standar Pasca Berlakunya Undang-Undang Perlindungan Konsumen" Makalah, Jogjakarta,
Penggunaan kontrak baku dalam dunia bisnis dewasa ini menimbulkan permasalahan hukum yang memerlukan pemecahan. Secara tradisional suatu perjanjian terjadi didasarkan pada asas kebebasan berkontrak di antara dua pihak yang memiliki kedudukan yang seimbang. Kesepakatan yang didapat dalam perjanjian itu merupakan hasil negosiasi di antara para pihak. Proses semacam itu tidak ditemukan dalam perjanjian baku. Hampir tidak ada kebebasan dalam menentukan isi perjanjian dalam proses negosiasi. Isi atau syarat-syarat perjanjian telah ditentukan secara sepihak oleh pengusaha ${ }^{2}$. Praktik tersebut di satu sisi sangat

hlm.1.

2 Ibid. 
menguntungkan pengusaha, namun di sisi lain menimbulkan kerugian bagi konsumen.

Penerapan perjanjian standar ini sejak awal kelahirannya hingga kini menimbulkan kontroversi baik menyangkut keberadaan dan keabsahan kontrak baku. Kitab UndangUndang Hukum Perdata (KUHPerdata) tidak secara spesifik mengatur baku. Kini dengan telah berlakunya Undang-Undang Perlindungan Konsumen (UUPK) masalah keabsahannya mulai terjawab.

Masyarakat menginginkan perjanjian atau kontrak tetap menjunjung asas-asas universal yang berlaku dalam hukum kontrak yaitu asas kebebasan berkontrak, asas kebebasan memilih hukum yang berlaku dan asas kebebasan menentukan yurisdiksi. Kenyataannya berbeda dimana adanya kecenderungan pelaku usaha untuk menutup suatu transaksi dengan terlebih dahulu telah menyiapkan format-format kontrak yang umumnya telah tercetak (modelled draft of contract) untuk ditandatangani oleh mitra berkontraknya. Disadari maupun tidak disadari hal itu telah menghilangkan atau paling tidak telah membatasi kebebasan berkontrak (freedom of contract) dari mitra berkontraknya untuk secara seimbang dapat menegosiasikan isi kesepakatan yang dapat diterimanya ${ }^{3}$.

Perdebatan tentang sah atau tidaknya suatu perikatan yang timbul dari suatu perjanjian standar (standardized contract) untuk mengikat ataupun berlaku sebagai hukum para pihak yang berkontrak sudah menjadi persoalan lama kelanjutan dari persoalan yang telah muncul di negara-negara yang telah lebih dahulu menghadapi permasalahan penggunaan pola kontrak standar tersebut, sebagai reaksi atau upaya masyarakat hukum untuk mencari ukuran keadilan, khususnya bagi pihak pengguna barang dan jasa (konsumen) yang lebih cenderung didudukkan pada posisi yang lemah.

Hal ini menunjukkan bahwa perlu adanya hukum yang tegas mengenai pelarangan klausul-klausul baku yang tidak adil yang

3 Ricardo Simanjuntak. (2003). "Akibat dan Tindakan-Tindakan Hukum Terhadap Pencantuman Klausula Baku Dalam Polis Asuransi Yang bertentangan dengan Pasal 18 sering digunakan oleh pelaku usaha untuk menekan konsumen tersebut, asas kebebasan berkontrak serta konsekuensi mengikatnya kesepakatan hukum bagi para pihak (pacta sunt servanda). ${ }^{4}$

\section{Rumusan Masalah}

Pertama, bagaimanakah keabsahan perjanjian dengan klausul baku?

Kedua, bagaimana akibat hukum ketiadaanasas kebebasan berkontrak dalam perjanjian?

\section{Tujuan Penelitian}

Pertama, untuk mendapatkan pemahaman yang lebih baik tentang keabsahan perjanjian dengan klausula baku. Kedua, untuk meneliti dan mengetahui tentang akibat hukum jika perjanjian tidak didasarkan pada asas kebebasan berkontrak

\section{Metode Penelitian}

Penelitian ini adalah metode penelitian normatif yang mengacu kepada peraturan perundangundangan dan putusan pengadilan. Penelitian ini mencakup penelitian terhadap asas-asas hukum dan faktor yang berkaitan dengan pokok bahasan penelitian ini. Oleh karena penelitian ini merupakan penelitian normatif, maka sumber datanya adalah berupa data sekunder. Data sekunder ini berupa bahan- bahan hukum. Penelitian ini menitikberatkan pada data sekunder berupa bahan hukum, untuk mendapatkan hal tersebut dilakukan pengumpulan data dengan cara studi kepustakaan. Pengolahan bahan hukum hanya ditujukan pada analisis bahan hukum secara deskriptif kualitatif, yaitu menguraikan bahan hukum sesuai dengan pokok permasalahan dalam penelitian ini, selanjutnya dianalisis berdasarkan teori yang berkaitan dengan

Undang-Undang No. 8 Tahun 1999 tentang Perlindungan Konsumen" Jurnal Hukum Bisnis, 22(2) : 53.

$4 \quad$ Ibid, hlm. 57. 
permasalahan untuk sampai pada kesimpulan.

\section{Hasil dan Pembahasan}

Keabsahan Perjanjian dengan Klausul Baku Untuk menentukan atau menilai keabsahan kontrak jual beli BTS yang dituangkan dalam perjanjian standar harus dikaji bagaimana hukum kontrak mengatur syarat- syarat keabsahan kontrak. Pasal 1320 KUHPerdata menentukan adanya 4 (empat) syarat sahnya suatu perjanjian, yakni: (1). Adanya kata sepakat bagi mereka yang mengikatkan dirinya; (2) kecakapan para pihak untuk membuat suatu perikatan; (3) harus ada suatu hal tertentu; dan (4) harus ada suatu sebab (causa) yang halal.

Persyaratan tersebut di atas berkenaan baik mengenai subjek maupun objek perjanjian. Persyaratan yang pertama dan kedua berkenaan dengan subjek perjanjian. Persyaratan yang ketiga dan keempat berkenaan dengan objek perjanjian. Pembedaan kedua persyaratan tersebut dikaitkan pula dengan masalah batal demi hukumnya (nieteg, null and void, void ab initio) dan dapat dibatalkannya (vernietigbaar, voidable) suatu perjanjian. Perjanjian yang batal demi hukum adalah perjanjian yang sejak semula sudah batal, hukum menganggap perjanjian tersebut tidak pernah ada. Perjanjian yang dapat dibatalkan adalah sepanjang perjanjian tersebut belum atau tidak dibatalkan pengadilan, maka perjanjian yang bersangkutan masih terus berlaku.

Pakar hukum Indonesia umumnya berpendapat bahwa apabila persyaratan subjektif perjanjian (kata sepakat dan kecakapan untuk melakukan perikatan) tidak dipenuhi tidak mengakibatkan batalnya perjanjian, tetapi hanya dapat dibatalkan melalui putusan pengadilan. Apabila persyaratan yang menyangkut objek perjanjian (suatu hal tertentu dan adanya causa hukum yang halal) tidak dipenuhi, maka perjanjian tersebut batal demi hukum.

Kata sepakat di dalam perjanjian pada dasarnya

5 J. Satrio. (1995). "Hukum Perikatan, Perikatan Yang Timbul dari Perjanjian". Bandung: Citra Adiyta Bakti. hlm. 164.

6 Mariam Darus Badrulzaman. (1994). "Aneka Hukum Bisnis". Bandung: Alumni. hlm. 24. adalah pertemuan atau persesuaian kehendak antara para pihak di dalam perjanjian. Seseorang dikatakan memberikan persetujuannya atau kesepakatannya (toestemming) jika ia memang menghendaki apa yang disepakati5. Mariam Darus Badrulzaman melukiskan pengertian sepakat sebagai persyaratan kehendak yang disetujui (overeenstemende wilsverklaring) antar pihakpihak. Pernyataan pihak yang menawarkan dinamakan tawaran (offerte). Pernyataan pihak yang menerima penawaran dinamakan akseptasi (accceptatie) ${ }^{6}$. Mengingat tidak adanya definisi penawaran tersebut, Rutten mendefinisikan penawaran sebagai suatu usul untuk menutup perjanjian yang ditujukan kepada pihak lawan janjinya, usul mana telah dirumuskan sedemikian rupa sehingga penerimaan usul itu langsung menimbulkan perjanjian?.

Pernyataan kehendak tersebut harus merupakan pernyataan bahwa ia menghendaki timbulnya hubungan hukum. Kesesuaian kehendak antara dua saja belum melahirkan perjanjian, karena kehendak tersebut harus dinyatakan, harus nyata bagi pihak yang lain, dan harus dapat dimengerti oleh pihak lain. Apabila pihak yang lain tersebut telah menyatakan menerima atau menyetujuinya, maka timbullah kata sepakat.

Orang dapat mengatakan bahwa suatu pernyataan adalah suatu penawaran apabila hal itu sampai pada orang yang diberikan penawaran, sedang pernyataan itu sendiri haruslah diartikan sebagai suatu tanda yang dapat diketahui dan dimengerti oleh lawan janjinya. Konsekuensinya, jika terjadi karena penawaran itu diterima secara keliru ada akseptasi yang menyimpang dari penawarannya maka pada dasarnya tidak lahir perjanjian ${ }^{8}$ J. Satrio menyebutkan ada beberapa cara untuk mengemukakan kehendak tersebut, yakni secara tegas, tertulis, dengan tanda, dan diam-diam. ${ }^{9}$

\footnotetext{
J. Satrio, Op. Cit., hlm. 166.

Ibid., hlm. 176.

Ibid., hlm. 183.
} 
Suatu perjanjian dapat mengandung cacat kehendak atau kata sepakat dianggap tidak ada jika terjadi hal-hal yang disebut di bawah ini, yaitu adanya paksaan (dwang), adanya kesesatan atau kekeliruan (dwaling), dan adanya penipuan (bedrog); dan dalam perkembangan lebih lanjut, dikenal pula cacat kehendak yang lain, yakni penyalahgunaan keadaan (misbruik van omstandigheden). ${ }^{10}$ Jadi, sekarang ini dikenal adanya empat kelompok bentuk cacat kehendak.

\section{Paksaan}

Menurut Pasal 1324 KUHPerdata, paksaan terjadi apabila perbuatan itu sedemikian rupa sehingga dapat menakutkan seseorang yang berpikiran sehat dan apabila perbuatan itu dapat menimbulkan ketakutan pada orang tersebut bahwa dirinya atau kekayaannya terancam dengan suatu kerugian yang terang dan nyata. Paksaan adalah kekerasan jasmani atau ancaman dengan sesuatu yang diperbolehkan hukum yang menimbulkan ketakutan sehingga ia membuat perjanjian. Di sini paksaan tersebut harus benar-benar menimbulkan suatu ketakutan bagi yang menerima paksaan ${ }^{11}$.

\section{Kekeliruan atau Kesesatan}

Kekeliruan terjadi apabila salah satu pihak khilaf tentang hal-hal yang pokok dari para yang diperjanjikan atau tentang syarat yang penting dari barang yang menjadi objek perjanjian atau mengenai orang dengan siapa perjanjian itu dilakukan. Kekhilalafan itu harus sedemikian rupa, hingga seandainya orang itu tidak khilaf mengenai hal tersebut, ia tidak akan memberikan persetujuannya ${ }^{12}$.

\section{Penipuan}

Penipuan terjadi apabila salah satu pihak dengan sengaja memberikan keteranganketerangan yang palsu atau tidak benar disertai dengan tipu muslihat untuk membujuk pihak lawannya memberikan persetujuannya, pihak

10 Ibid., hlm. 268.

11 Mariam Darus Badrulzaman. (2001). “Kompilasi Hukum Perikatan, Bandung: Citra Aditya Bakti. hlm. 65.

12 R. Subekti. (1984). "Hukum Perjanjian". Jakarta: Intermasa. hlm. 24. yang menipu bertindak secara aktif untuk menjerumuskan pihak lawannya ${ }^{13}$.

Penipuan adalah dengan sengaja mengajukan gambaran atau fakta yang salah untuk memasuki hubungan kontrak. Oleh karena itu, pihak yang tidak bersalah harus bersandar pada gambaran yang salah tadi dan secara finansial pihak yang merugikan pihak lain itu wajib membayar ganti rugi. ${ }^{14}$

Menurut doktrin dan yurisprudensi, ternyata perjanjian-perjanjian yang mengandung cacat seperti itu tetap mengikat para pihak, hanya saja, pihak yang merasakan telah memberikan pernyataan yang mengandung cacat tersebut dapat memintakan pembatalan perjanjian. Sehubungan dengan ini, Pasal 1321 KUHPerdata menyatakan bahwa jika di dalam suatu perjanjian terdapat kekhilafan, paksaan atau penipuan, maka berarti di dalam perjanjian itu terdapat cacat pada kesepakatan antar para pihak dan karenanya perjanjian itu dapat dibatalkan".

Syarat sahnya perjanjian yang kedua menurut Pasal 1320 KUHPerdata adalah kecakapan untuk membuat perikatan (om eene verbintenis aan te gaan). Pasal 1329 KUHPerdata menyatakan bahwa setiap orang adalah cakap untuk membuat perjanjian, kecuali apabila menurut undang-undang dinyatakan tidak cakap. Kemudian Pasal 1330 menyatakan bahwa ada beberapa orang tidak cakap untuk membuat perjanjian, yakni: orang yang belum dewasa; mereka yang ditaruh di bawah pengampuan; dan orang-orang perempuan, dalam hal-hal yang ditetapkan oleh undangundang dan pada umumnya semua orang kepada siapa undang-undang telah melarang membuat perjanjian tertentu.

Seseorang dikatakan belum dewasa menurut Pasal 330 KUHPerdata jika belum mencapai umur 21 tahun. Seseorang dikatakan dewasa jika telah berumur 21 tahun atau berumur kurang dari 21 tahun, tetapi telah menikah.

13 Ibid.

14 Salim H.S. (2003). "Hukum Kontrak, Teori dan Teknik Penyusunan Kontrak, Jakarta: Sinar Grafika. hlm. 27 
Dalam perkembangannya, berdasar Pasal 47 dan 50 UU No. 1 Tahun 1974 tentang UU Perkawinan, kedewasaan seseorang ditentukan bahwa anak berada di bawah kekuasaan orang tua atau wali sampai umur 18 tahun. Selanjutnya Mahkamah Agung melalui Putusan No. 447/Sip/1976 tanggal 13 Oktober 1976 menyatakan bahwa dengan berlakunya UU No. 1 Tahun 1974, maka batas seseorang berada di bawah kekuasaan perwalian adalah 18 tahun, bukan 21 tahun.

Seseorang yang telah dewasa dapat tidak cakap melakukan perjanjian, jika yang bersangkutan diletakkan di bawah pengampuan (curatele atau conservatorship). Seseorang dapat diletakkan di bawah pengampuan jika yang bersangkutan gila, dungu (onnoozelheid), mata gelap (razernij), lemah akal (zwakheid van vermogens) atau juga pemboros. Orang yang demikian itu tidak menggunakan akan sehatnya, dan oleh karenanya dapat merugikan dirinya sendiri.

Syarat sahnya perjanjian yang ketiga adalah adanya suatu hal tertentu (een bepaald onderwerp). Pasal 1333 KUHPerdata menentukan bahwa suatu perjanjian harus mempunyai pokok suatu benda (zaak) yang paling sedikit dapat ditentukan jenisnya.

Suatu perjanjian harus memiliki objek tertentu. Suatu perjanjian harus mengenai suatu hal tertentu berarti bahwa apa yang diperjanjikan, yakni hak dan kewajiban kedua belah pihak. Barang yang dimaksudkan dalam perjanjian paling sedikit dapat ditentukan jenisnya.

Istilah barang dimaksud di sini apa yang dalam bahasa Belanda disebut sebagai zaak. Zaak dalam bahasa Belanda tidak hanya berarti barang dalam arti sempit, tetapi juga berarti yang lebih luas lagi, yakni pokok persoalan. Oleh karena itu, objek perjanjian tidak hanya berupa benda, tetapi juga bisa berupa jasa.

J. Satrio menyimpulkan bahwa yang dimaksud dengan suatu hal tertentu dalam perjanjian adalah objek prestasi perjanjian. Isi prestasi tersebut harus tertentu atau paling sedikit dapat ditentukan jenisnya ${ }^{15}$. KUHPerdata menentukan bahwa barang yang dimaksud tidak harus disebutkan, asalkan nanti dapat dihitung atau ditentukan. Misalnya mengenai perjanjian "panen tembakau dari suatu ladang dalam tahun berikutnya" adalah sah. Perjanjian jual beli "teh untuk seribu rupiah" tanpa penjelasan lebih lanjut, harus dianggap tidak cukup jelas.

Syarat sahnya perjanjian yang keempat adalah adanya kausa hukum yang halal. Kata kausa yang diterjemahkan dari kata oorzaak (Belanda) atau causa (Latin) bukan berarti sesuatu yang menyebabkan seseorang membuat perjanjian, tetapi mengacu kepada isi dan tujuan perjanjian itu sendiri. Misalnya dalam perjanjian jual beli, isi dan tujuan atau kausanya adalah pihak yang satu menghendaki hak milik suatu barang, sedangkan pihak lainnya menghendaki uang.

Menurut Pasal 1335 jo 1337 KUHPerdata bahwa suatu kausa dinyatakan terlarang jika bertentangan dengan undang-undang, kesusilaan, dan ketertiban umum. Suatu kausa dikatakan bertentangan dengan undangundang, jika kausa di dalam perjanjian yang bersangkutan isinya bertentangan dengan undang-undang yang berlaku.

Untuk menentukan apakah suatu kausa perjanjian bertentangan dengan kesusilaan (goede zeden) bukanlah masalah yang mudah, karena istilah kesusilaan tersebut sangat abstrak, yang isinya bisa berbeda-beda antara daerah yang satu dan daerah atau antara kelompok masyarakat yang satu dan lainnya. Selain itu penilaian orang terhadap kesusilaan dapat pula berubah-ubah sesuai dengan perkembangan zaman.

J. Satrio mempermasalahkan, apakah kausa hanya tidak boleh bertentangan dengan kesusilaan yang bersifat umum ataukah hanya dalam lingkup yang terbatas. Dalam hal ini terdapat dua pendapat. Pendapat yang satu hanya mau menerima "kesusilaan" dalam lapangan, yakni kalau ia merupakan penerapan moral umum dalam kalangan terbatas atau hubungan hukum tertentu. Pendapat yang lain, yakni pendapat yang lebih luas, yang mau menerima "kesusilaan" dalam kalangan yang terbatas, asal tidak bertentangan dengan

15 J. Satrio., Op. Cit., hlm. 41. 
kesusilaan umum. Brakel lebih setuju dengan pendapat yang sempit, alasan sulit menuntut hakim agar ia menerapkan norma moral, yang tidak diyakininya, karena ia sendiri bukan berasal dari kalangan di mana moral itu berlaku, dan oleh karenanya tidak sesuai dengan kesadaran moralnya.

Kausa hukum dalam perjanjian yang terlarang juga apabila bertentangan ketertiban umum. J. Satrio memaknai ketertiban umum sebagai halhal yang berkaitan dengan masalah kepentingan umum, keamanan negara, keresahan dalam masyarakat, dan karenanya dapat dikatakan berkaitan masalah ketatanegaraan.

Dalam beberapa perkara yang terdapat klausul eksonerasi yang dimuat dalam kontrak. Hoge Raad dalam perkara memberikan pertimbangan bahwa dalam keadaan tertentu yang berbeda satu dengan lainnya, klausul eksonerasi tidak berlaku lagi, karena bertentangan dengan iktikad baik. ${ }^{16}$

Setelah berlaku efektifnya seluruh ketentuan BW (baru) Belanda sejak 1 Januari 1992, problem klausul baku atau standar mulai mendapat pengaturan khusus dengan titel algemene voorwaarden. Menurut Pasal 6.232 BW (baru), suatu klausul menjadi terlarang jika pihak lain yang terikat kepada klausul baku kalau pada saat mengadakan kontrak, pengguna klausul itu mengerti atau seharusnya mengetahui bahwa pihak lainnya tidak mengetahui isi persyaratan baku tersebut. Kemudian menurut Pasal 6.233 BW (baru), suatu perjanjian dengan klausul baku dapat dibatalkan: 1. Jika dengan memperhatikan berbagai keadaan yang meliputi kontrak tersebut bersifat sangat bertentangan dengan akal sehat; atau 2. Jika pihak yang menuntut dicantumkannya klausul baku, tidak memberikan kesempatan kepada pihak lawannya untuk memperoleh penjelasan tentang klausul-klausul itu.

KUHPerdata Indonesia belum mengantisipasi hal tersebut, namun demikian berkaitan dengan hubungan antara produsen dan konsumen terdapat pulapengaturan tentang klausul baku ini dalam Undang-Undang Nomor 8 Tahun 1999. Pasal 18 ayat (1) menentukan pelaku usaha dalam menawarkan barang dan/atau jasa yang ditujukan untuk diperdagangkan dilarang membuat atau mencantumkan klausul baku di setiap dokumen dan/atau perjanjian apabila: a. menyatakan pengalihan tanggung jawab pelaku usaha; b. menyatakan bahwa pelaku usaha berhak menolak penyerahan kembali barang yang telah dibeli konsumen; c. menyatakan bahwa pelaku usaha berhak menolak penyerahan kembali uang yang dibayarkan atas barang dan/atau jasa yang dibeli oleh konsumen; d. menyatakan pemberian kuasa dari konsumen kepada pelaku usaha baik secara langsung maupun tidak langsung untuk melakukan segala tindakan sepihak yang berkaitan dengan barang yang dibeli oleh konsumen secara angsuran; e. mengatur perihal pembuktian atas hilangnya kegunaan barang atau pemanfaatan jasa yang dibeli oleh konsumen; f. memberi hak kepada pelaku usaha untuk mengurangi manfaat jasa atau mengurangi harta kekayaan konsumen yang menjadi yang menjadi objek jual beli jasa; g. menyatakan tunduknya konsumen kepada peraturan berupa aturan baru, tambahan, lanjutan dan/atau pengubahan lanjutan yang dibuat sepihak oleh pelaku usaha dalam masa konsumen memanfaatkan jasa yang dibelinya; h. menyatakan bahwa konsumen memberi kuasa kepada pelaku usaha untuk pembebanan hak tanggungan, hak gadai, atau hak jaminan teradap barang yang dibeli oleh konsumen secara angsuran.

Dalam ayat (2) kemudian ditentukan pula bahwa pelaku usaha dilarang mencantum klausul baku yang letak atau bentuknya sulit terlihat atau tidak dapat dibaca secara jelas, atau yang pengungkapannya sulit dimengerti.

Larangan tersebut di atas oleh ayat (3) pasal itu dikaitkan dengan kausa hukum yang halal dalam kontrak. Jika kontrak memuat klausul yang dilarang tersebut, maka konsekuensinya, kontrak yang bersangkutan batal demi hukum.

Hoge Raad telah memberikan rumus-rumus

16 P.L. Wery, Op. Cit., hlm. 13. Lihat juga Setiawan. (1994). "Kontrak Standar dalam Teori dan Praktek”. Varia Peradilan. IX(103): 149 - 150. 
yang bagus sekali untuk pengujian syarat-syarat iktikad baik pada kontrak. Rumus-rumus beraneka ragam dan memperhitungkan keadaan yang ada hubungannya dengan pelaksanaan kontrak. Dengan demikian, hakim dalam suatu sengketa konkrit antara dua pihak yang mengadakan kontrak memiliki ukuran pengujian yang tajam, yang memenuhi hukum alam semua keadaan dari sengketa itu ${ }^{17}$.

Mestinya sepanjang tidak memenuhi persyaratan yang dimaksud Pasal 1320 KUHPerdata, maka kontrak dengan klausul baku tetap sah. Kontrak tersebut jika tidak memenuhi syarat subjektif dapat dibatalkan melalui gugatan pembatalan kontrak ke pengadilan. Kemudian jika berkaitan dengan persyaratan objektif, maka kontrak batal demi hukum.

Sekarang ini bukan dipersoalkan sah tidaknya kontrak klausul baku, tetapi apakah isi perjanjian itu ada yang memuat klausul yang dilarang oleh Undang- Undang Perlindungan Konsumen. Demikian juga apakah isi kontrak memuat klausul yang mengandung ketidakrasionalan dan ketidakpatutan.

Akibat Hukum Kontrak yang Tidak Menerapkan Kebebasan Berkontrak

Adanya persyaratan kata sepakat di antara pihak yang mengadakan perjanjian, mengakibatkan kedua belah pihak haruslah mempunyai kebebasan untuk menyatakan kehendaknya, dalam hal ini para pihak tidak boleh mendapat sesuatu tekanan yang mengakibatkan adanya cacat bagi perwujudan kehendak tersebut.

Meskipun telah ada pembatasan-pembatasan atas daya kerja atas asas kebebasan berkontrak, namun batasan-batasan tersebut ternyata masih longgar. hal ini menimbulkan suatu keadaan yang tak terbatas, sehingga dalam perkembangannya pembuatan perjanjian yang semata-mata hanya berlandaskan pada bekerjanya asas kebebasan berkontrak praktis

17 Ridwan Khairandy. (2004) "Iktikad Baik dalam Kebebasan Berkontrak". Jakarta: Pascasarjana Fakultas Hukum Universitas Indonesia. hlm. 249.

18 Setiawan. (1993). "Dari Up Grading dan Refreshing Course Notaris, Pembahasan Ihwal tidak terbatas lagi, yang akhirnya akan merupakan ajang perebutan dominasi antara para pihak, yaitu pihak yang kuat akan berusaha untuk memaksakan kehendaknya terhadap pihak yang lebih lemah ${ }^{18}$.

Perkembangan tersebut di atas, pada akhirnya akan menimbulkan perjanjian yang bukan saja berat sebelah atau timpang, tetapi juga sering mengandung klausula- klausula yang secara tidak wajar memberatkan pihak yang lemah, misalnya klausula- klausula eksemsi atau eksenorasi ataupun perjanjian dengan klausula baku seperti yang sekarang umum dijumpai di dalam dunia bisnis. Pasal 1313 KUH Perdata telah memberikan definisi yang cukup jelas perihal apa yang dimaksud dengan suatu perjanjian ataupun persetujuan, yaitu, suatu perbuatan dengan mana satu orang atau lebih mengikatkan dirinya terhadap satu orang lain atau lebih.

Wirjono Prodjodikoro lebih rinci lagi di dalam memberikan arti dari suatu perjanjian yaitu suatu perhubungan hukum mengenai harta benda antar dua pihak, dalam mana satu pihak berjanji atau dianggap berjanji untuk melakukan sesuatu hal atau untuk tidak melakukan sesuatu hal, sedang pihak lain berhak menuntut pelaksanaan perjanjian itu ${ }^{19}$.

Sebagaimana kita ketahui bersama, berlakunya KUHPerdata kita ini karena diterapkannya asas konkordasi oleh pemerintah kolonial Belanda sehingga KUH Perdata kita merupakan duplikasi dari KUH Perdata Belanda, sedangkan KUH Perdata Belanda juga merupakan duplikasi dari Code Civil Perancis. Hal tersebut adalah wajar oleh karena Indonesia bekas jajahan Belanda dan Belanda adalah bekas jajahan Perancis. Revolusi Perancis telah mengilhami ketentuan Pasal 1338 KUH Perdata, sebab dengan berpijak pada jiwa dari revolusi Perancis tersebut yang menempatkan individu sebagai dasar dari semua kekuasaan.

Paham tersebut di atas menimbulkan konsekuensi bahwa orang juga bebas untuk

Kebebasan Berkontrak". News Letter No. 13 /IV/Juni. hlm. 13.

19 Wirjono Prodjodikoro. (1986). Asas-asas Hukum Perjanjian. Bandung: Alumni Bandung. hlm. 4 
mengikatkan diri dengan orang lain, kapan dan bagaimana yang diinginkan serta kontrak terjadi berdasarkan kebebasan kehendak yang mempunyai kekuatan mengikat sebagai undang-undang ${ }^{20}$. Di dalam kontrak jual beli BTS pada dasarnya tidak didasarkan pada asas kebebasan berkontrak, karena tidak ada konsensus atau kata sepakat yang sebenarnya. Padahal asas konsensualisme dalam kontrak menjadi hal yang mendasar. Di sini terdapat cacat kehendak.

Pada dasarnya dalam kenyataannya (de facto) "isi perjanjiannya tidak diketahui" oleh pihak yang disodori perjanjian standar, ini menjadi salah satu alasan pokok keberatan. Dan katanya, bahwa kalaupun mereka tahu isinya, belum tentu mereka maksud dan jangkauan daripada klausula-klausula yang ada disana. Ada yang merinci keberatan-keberatannya antara lain dituangkan dalam suatu formulir, isinya tidak diperbincangkan lebih dahulu : pihak yang disodori perjanjian standar "terpaksa" menerima keadaan itu karena posisinya yang lemah dan karenanya disebut dwangcontracten, dimana kebebasan berkontrak berdasarkan Pasal 1338 KUH Perdata sudah dilanggar. Perjanjian (standar) kredit merupakan pencetusan dari kekuatan ekonomi bank sebagai pemberi kredit yang "menekan" penerima kredit. Ada pula yang menyebutkan bahwa "paksaan syarat-syarat tersebut ada diantaranya menjadi tidak normal, tidak berlaku sebagaimana mestinya"

Ketiadaan kata sepakat atau kata sepakat yang tidak betul-betul bulat tidak mengakibatkan batalnya kontrak. Jika kekurangan yang berkaitan dengan perjanjian, yakni kata sepakat dan kedewasaan hanya mengakibatkan kontrak dapat dibatalkan. Artinya sepanjang kontrak tersebut telah dilaksanakan dan tidak ada pihak keberatan dan meminta pembatalan kontrak ke pengadilan, kontrak tetap sah. Namun jika kekurangan itu berkaitan syarat objektif, yakni tiadanya syarat objek tertentu bertentangan dengan kausa yang halal, maka kontrak tersebut batal demi hukum. Artinya sejak awal sudah tidak dan dianggap tidak pernah ada.

Untuk lebih jelas mengenai akibat hukum apabila syarat sahnya kontrak tidak terpenuhi. Hal ini bervariasi tergantung pada syarat apa yang tidak dipenuhi di dalam kontrak tersebut, yang antara lain :

Pertama, kontrak tersebut batal demi hukum (nietig, null and void), bilamana kontrak tersebut tidak memenuhi syarat obyektif dari suatu kontrak. Adapun syarat obyektif dari suatu kontrak adalah perihal tertentu dan kuasa yang legal sebagaimana yang tercantum di dalam Pasal 1320 KUH Perdata.

Kedua, kontrak tersebut dapat dibatalkan (vernietigbaar, voidable), bilamana kontrak tersebut tidak memenuhi syarat subyektif dari suatu kontrak. Adapun syarat subyektif dari suatu kontrak adalah perihal kesepakatan kehendak dan kecakapan berbuat sebagaimana yang tercantum di dalam Pasal $1320 \mathrm{KUH}$ Perdata. Kontrak tersebut tidak dapat dilaksanakan (unenforceable), yaitu kontrak yang belum mempunyai kekuatan hukum sebelum dikonversi menjadi kontrak yang sah. Sebagai contoh dari kontrak yang tidak dapat dilaksanakan tersebut adalah kontrak yang seharusnya dibuat secara tertulis, tetapi oleh para pihak ternyata dibuat secara lisan. Untuk mengatasi permasalahan tersebut, oleh para pihak kontrak tersebut kemudian dibuat secara tertulis.

Dijatuhi sanksi administrasi pada para pihak atau salah satu pihak yang terikat suatu kontrak tersebut, misalnya bilamana terhadap suatu kontrak memerlukan izin atau pelaporan terhadap instansi tertentu, seperti izin pelaporan kepada Bank Indonesia untuk suatu kontrak off shore loan. Jika salah satu atau kedua pihak tidak melaksanakan kewajibannya, maka perjanjian dapat dibatalkan. Pembatalan dapat dilakukan oleh pihak-pihak dalam hal ada kesepakatan dalam perjanjian. Namun demikian, jika tidak diperjanjikan dan salah satu pihak tidak setuju, pembatalan tersebut dapat dilakukan melalui putusan pengadilan.

20 Purwahid Patrik. (1986). Asas Iktikad Baik dan Kepatutan Dalam Perjanjian. Semarang: Badan Penerbit UNDIP. hlm. 4. 
Putusan pengadilan adalah perlu untuk menyatakan pembatalan. Pihak yang berkepentingan harus mengajukan permohonan kepada pengadilan supaya persetujuan yang dibuatnya dibatalkan. Andaikata pengadilan mengabulkan permohonan tersebut, maka persetujuan yang dibatalkan tersebut menjadi batal dari semula. Persetujuan tersebut mempunyai akibat-akibat hukum, namun kita harus memperhitungkan bahwa akibat-akibat tersebut pada suatu ketika dapat dibatalkan.

Jika terjadi pembatalan maka perjanjian berakhir, kewajiban yang telah dilaksanakan dapat dipulihkan kembali dan yang belum dilaksanakan supaya dihentikan pelaksanaannya atau tidak perlu sama sekali. Namun, bagaimanapun juga perjanjian itu mengikat, dan masing-masing pihak harus bertanggung jawab terhadap apa yang telah dijanjikan dalam perjanjian itu. Manusia adalah manusia yang umumnya ingin mencari keuntungan sendiri dengan dalam mengurangi tanggung jawabnya, meringankan bahkan kalau mungkin menghapuskan sama sekali tanggung jawabnya dalam ikatan perjanjian yang dibuatnya. Maka dari itu dalam banyak perjanjian kadang-kadang kita membaca syaratsyarat yang dicantumkan dalam perjanjian itu maksudnya terutama ialah ingin menghapuskan atau membatasi tanggung jawab salah satu pihak dalam perjanjian itu. Kadang-kadang orang mengambil sikap apa boleh buat karena adanya kebutuhan yang mendesak sehingga ia terpaksa menandatangani perjanjian itu.

Ketentuan hukum kontrak di Indonesia memang menekankan bahwa kesepakatan yang dicapai para pihak sebagai salah satu dasar fundamental pembentukan perjanjian atau kontrak yang sah haruslah tidak didasarkan oleh karena adanya paksaan ataupun penipuan (misrepresentasi) ataupun kekhilafan dari pihak lainnya, dimana bila kesepakatan tersebut kemudian dibuktikan dicapai oleh upaya yang dimaksud dalam Pasal 1321 KUH Perdata tersebut, maka akan memberikan hak bagi pihak yang dirugikan untuk memintakan pembatalan pada kontrak yang telah secara formal disepakati ataupun ditandatangani oleh para pihak tersebut.
Akibat hukum terhadap klausul-klausul yang dianggap dapat merugikan kepentingan ataupun hak dari pihak mitra berkontrak yang posisinya lemah yang secara sadar sering dipaksakan oleh pengusaha yang mempunyai posisi yang lebih kuat untuk dipasangkan sebagai point perikatan ataupun klausula baku dalam suatu kontrak, pada umumnya tidak diatur dengan secara tegas dalam ketentuan hubungan kontrak Indonesia.

Pasal 1338 ayat (3) KUHPerdata hanya menasehatkan bahwa suatu perjanjian harus dilaksanakan dengan iktikad baik, dimana ketentuan ini tidak memberikan akibat yang signifikan untuk dapat membatalkan suatu perjanjian yang telah ditandatangani oleh para pihak yang oleh Pasal 1338 ayat KUHPerdata secara tegas diakui mempunyai kekuatan sebagai undang-undang (bahkan berlaku sebagai lex specialis) yang berlaku dan mengikat para pihak yang menandatangani kontrak tersebut. Kemungkinan yang lebih dapat menjaga agar tidak terjadi kesewenangwenangan oleh pihak yang posisinya lebih lemah.

Suatu perjanjian tidak hanya untuk hal-hal yang dengan jelas dinyatakan didalammnya, tetapi juga untuk segala sesuatu yang menurut sifat perjanjian diharuskan oleh kepatutan, kebiasaan atau undang-undang". Pasal ini belum secara tegas dapat melindungi kepentingankepentingan klausula-klausula baku yang sering lebih berbentuk klausula eklsempsi (exeplaion clause, exclusion clause). Karena kekuatan dari konsekuensi ditandatanganinya suatu kontrak yang memberikan pengertian berdasarkan hukum kontrak Indonesia bahwa kedua belah pihak telah melakukan kewajiban "duty of care" ataupun "duty to real" membuat sulit bagi pengadilan untuk menerima adanya langkah-langkah untuk melindungi hak-hak dari pihak yang lemah atas dasar kerugiankerugian yang muncul dari akibat diberlakukannya klausula eksempsi ataupun 
klausul limitasi tersebut ${ }^{21}$.

Khususnya dalam suatu naskah kontrak tercetak yang diajukan kepada pihak konsumen untuk ditandatangani, dimana sebenarnya sebelum langkah yang menandatangani kontrak tersebut, tetap saja undang-undang masih melihat bahwa konsumen tersebut mempunyai hak dan kewajiban untuk membaca (duty to read) dan memahami serta melakukan perubahan terhadap draft kontrak yang tercetak tersebut (duty to care) walaupun diakui situasi posisi konsumen yang cenderung berada pada posisi yang dibutuhkan sulit untuk melakukan hal tersebut.

Kemungkinan yang sangat tegas yang membuat konsumen atau pihak yang lemah tersebut dapat menghindar dari suatu kerugian akibat dari kehadiran klausula baku tersebut adalah apabila klausula baku yang dipaksakan tersebut bertentangan dengan kepentingan publik, kesusilaan ataupun bertentangan dengan undang- undang yang berlaku, yang membuat perjanjian tersebut menjadi batal demi hukum atau dasar pelanggaran keharusan klausul halalnya suatu perjanjian tersebut seperti yang dimaksudkan oleh Pasal 1337 KUHPerdata. Artinya, harus ada ketegasan dari undang-undang untuk melarang potensipotensi penggunaan perjanjian baku (khususnya yang tidak menggunakan persetujuan ataupun tanda tangan dari konsumen pada saat pemberlakuannya) yang sering diberlakukan secara paksa oleh situasi, ataupun klausula-klausula baku yang dimaksudkan untuk melindungi kepentingan pihak-pihak pengusaha, penjual, perusahaan asuransi ataupun perbankan, baik melalui cetak huruf yang sengaja diperkecil dengan warna yang buram dan sulit untuk dibaca, ataupun peletakan klausula tersebut pada bagian tersembunyi dari kontrak ataupun peletakan klausula tersebut pada bagian terpisah akan tetapi tetap secara niat dimaksudkan dalam suatu kesatuan dengan kontrak tersebut.

Tanpa kehadiran undang-undang yang secara khusus melarang digunakannya bentuk-bentuk perjanjian baku ataupun klausula baku tidak

21 Sutan Remy Sjahdeini.. (1993). Kebebasan Berkontrak dan Perlindungan yang Seimbang bagi seimbang dan tidak adil serta tidak memberikan perlindungan atau bahkan merugikan kepentingan dari konsumen tersebut, tetap saja pengadilan masih enggan menjadikan dasar dari pencantuman klausula baku tersebut sebagai dasar untuk membatalkan suatu kontrak ataupun paling tidak membatalkan keberlakuan dari klausula baku yang merugikan tersebut.

\section{Penutup}

Pertama, sepanjang tidak memenuhi persyaratan yang dimaksud Pasal 1320 KUHPerdata, maka kontrak dengan klausul baku tetap sah. Kontrak tersebut jika tidak memenuhi syarat subjektif dapat dibatalkan melalui gugatan pembatalan kontrak ke pengadilan. Kemudian jika berkaitan dengan persyaratan objektif, maka kontrak batal demi hukum. Dengan demikian, sekarang ini tidak lagi dipersoalkan sah tidaknya kontrak dengan klausul baku, tetapi apakah isi perjanjian itu ada yang memuat klausul yang dilarang oleh Undang-Undang Perlindungan Konsumen. Demikian juga apakah isi kontrak memuat klausul yang mengandung ketidakrasionalan dan ketidakpatutan.

Kedua, Ketentuan hukum kontrak di Indonesia memang menekankan bahwa kesepakatan yang dicapai para pihak sebagai salah satu dasar fundamental pembentukan perjanjian atau kontrak yang sah haruslah tidak didasarkan oleh karena adanya paksaan ataupun penipuan ataupun kekhilafan dari pihak lainnya, dimana bila kesepakatan tersebut kemudian dibuktikan dicapai oleh upaya yang dimaksud dalam Pasal 1321 KUH Perdata tersebut, maka akan memberikan hak bagi pihak yang dirugikan untuk memintakan pembatalan pada kontrak yang telah secara formal disepakati ataupun ditandatangani oleh para pihak tersebut.

\section{Daftar Pustaka}

\section{Buku}

J. Satrio. (1995). “Hukum Perikatan, Perikatan

Para pihak dalam Perjanjian Kredit Bank di Indonesia. Jakarta: Institut Bankir di Indonesia. hlm. 65. 
Yang Timbul dari Perjanjian". Bandung: Citra Adiyta Bakti.

Mariam Darus Badrulzaman. (1994). "Aneka Hukum Bisnis". Bandung: Alumni.

Mariam Darus Badrulzaman. (2001). “Kompilasi Hukum Perikatan, Bandung: Citra Aditya Bakti

Purwahid Patrik. (1986). Asas Iktikad Baik dan Kepatutan Dalam Perjanjian. Semarang: Badan Penerbit UNDIP.

R. Subekti. (1984). “Hukum Perjanjian". Jakarta: Intermasa.

Ridwan Khairandy. (2004) "Iktikad Baik dalam Kebebasan Berkontrak". Jakarta: Pascasarjana Fakultas Hukum Universitas Indonesia.

Ridwan Khairandy. (2007). "Keabsahan Perjanjian Standar Pasca Berlakunya UndangUndang Perlindungan Konsumen" Makalah.

Salim H.S. (2003). "Hukum Kontrak, Teori dan Teknik Penyusunan Kontrak, Jakarta: Sinar Grafika.

Sutan Remy Sjahdeini. (1993). Kebebasan Berkontrak dan Perlindungan yang Seimbang bagi Para pihak dalam Perjanjian Kredit Bank di Indonesia. Jakarta: Institut Bankir di Indonesia.

Wirjono Prodjodikoro. (1986). Asas-asas Hukum Perjanjian. Bandung: Alumni Bandung.

\section{Jurnal}

Ricardo Simanjuntak. (2003). "Akibat dan Tindakan-Tindakan Hukum Terhadap Pencantuman Klausula Baku Dalam Polis Asuransi Yang bertentangan dengan Pasal 18 Undang-Undang No. 8 Tahun 1999 tentang Perlindungan Konsumen" Jurnal Hukum Bisnis, 22(2) : 53 .

Setiawan. (1993). “Dari Up Grading dan Refreshing Course Notaris, Pembahasan Ihwal Kebebasan Berkontrak". News Letter No. 13 /IV/Juni. hlm. 13.

Setiawan. (1994). “Kontrak Standar dalam Teori dan Praktek". Varia Peradilan. IX(103): 149 - 150. 